\title{
Light requirements and depth zonation of marine macroalgae
}

\author{
Stiig Markager*, Kaj Sand-Jensen** \\ Botanical Institute, Aarhus University, Nordlandsvej 68, DK-8240 Risskov, Denmark
}

\begin{abstract}
Light compensation points $\left(I_{c}\right)$ for growth were low $\left(0.3\right.$ to $\left.2.5 \mu \mathrm{mol} \mathrm{m}^{-2} \mathrm{~s}^{-1}\right)$ for the temperate marine macroalgae Chondrus crispus, Fucus serratus, Petalonia fascia, Porphyra purpurea and Ulva lactuca measured at $7^{\circ} \mathrm{C}$. These $I_{\mathrm{c}}$-values corresponded to those estimated by a physiological model including light absorption and quantum yield for growth to describe carbon gain, and weight specific dark respiration, dark loss rate and thallus specific carbon ( $\mathrm{mol} \mathrm{C} \mathrm{m}^{-2}$ thallus) to describe carbon loss. Absorption and quantum yield were close to the theoretical maximum for all species and could not explain differences in $I_{c}$. Respiration and thallus specific carbon varied more than 15 -fold and were the main factors responsible for variations in $I_{c}$. Experimental $I_{c}$-values correspond to 0.12 to $0.61 \%$ of the yearly surface light dose in Denmark $\left(56^{\circ} \mathrm{N}\right)$. These values agree with the \% of surface light (\%SI) available at the depth limits of leathery and foliose macroalgae at different latitudes. Hence, there is no surplus of energy to balance grazing and mechanical losses, and these factors must be of minor importance for macroalgae growing at great depths. A literature review of depth limits for marine macroalgae reveals an upper zone of mainly leathery algae with depth limits of about $0.5 \% \mathrm{SI}$, an intermediate zone of foliose and delicate algae with depth limits at about $0.10 \% \mathrm{SI}$, and a lower zone of encrusted algae extending down to about $0.01 \%$ SI. This zonation pattern is accompanied by a decrease in thallus specific carbon (i.e. thinner thalli) with increasing depth. The inverse relationship between growth rate at low light and thallus specific carbon suggests that a thin thallus is essential for growth and survival of marine macroalgae at great depths.
\end{abstract}

\section{INTRODUCTION}

The light compensation point $\left(I_{c}\right)$ for growth of marine macroalgae is a central parameter in coastal ecology. Attached macroalgae are important in many coastal ecosystems as primary producers (Mann 1973, 1982) and structural components with a rich macrofauna. The light compensation point sets the physiological constraints for the depth limit of attached macroalgae and affects the ability of macroalgae to grow in shaded habitats, below rocks or canopies of other algae, and to sustain epiphyte loads. Despite the importance, however, few determinations of $I_{c}$ for growth of marine macroalgae are available (Chapman

\footnotetext{
Present addresses:

- Institute of Life Sciences and Chemistry, Roskilde University, PO Box 260, DK-4000 Roskilde, Denmark

- Freshwater Biological Laboratory, University of Copenhagen, Helsingergade 51, DK-3400 Hillerod, Denmark
}

\& Lindley 1980, Schonbeck \& Norton 1980, Maggs \& Guiry 1987, Sand-Jensen 1988a). Here we determine $I_{\mathrm{c}}$-values of marine red, brown and green macroalgae displaying a range of thallus thicknesses.

The minimum light requirement for a plant is reached when captured light provides just enough ATP and reducing equivalents to balance loss processes within the tissue. Both the ability to capture and utilize light and the loss processes in the plant depend on several physiological parameters which, accordingly, affect the light compensation point. The common method to determine $I_{c}$ for growth is to plot growth rates $(y)$ vs light $(x)$ for low light intensities. This method only allows judgement of the relative importance of the $y$-axis intercept (loss rate in the dark) and the slope of the line (light utilization efficiency) for the regulation of $I_{c}$ ( $x$-axis intercept), and parameters which influence the dark loss rate and the light utilisation efficiency cannot be evaluated. In this paper we examine how the $I_{c}$-level of macroalgae depends on 
the basic physiological parameters: weight specific respiration, thallus specific carbon content (carbon per thallus area, analogous to 'leaf specific mass'; Witkowski \& Lamont 1991), light absorption and quantum yield for growth.

Light compensation points measured in laboratory experiments and depth limits in nature are difficult to compare. Laboratory measurements of $I_{\mathrm{C}}$ represent the absolute (or physiological) minimum light requirements. In nature, macroalgae may need a surplus of energy to balance grazing and mechanical damage and to allow physiological adjustments to environmental changes. The natural light climate is very variable and light intensities above saturation are utilized less efficiently than low light. A surplus of energy is also needed to form new biomass and reproductive units. The mean light intensity at the depth limit is, therefore, expected to be significantly higher than laboratory measurements of $I_{c}$ and differences between the two may quantify the extra energy needed to balance losses in the field. Here we compare our experimental $I_{c}$-values with literature values of light availability at the maximum depth of macroalgal growth.

\section{MATERIALS AND METHODS}

Laboratory growth experiments were described in detail by Markager (in press). Briefly, attached individuals of 5 marine macroalgae were collected in Århus Bay, Denmark, (salinity about $20 \%$ ) and cut into discs (Ulva lactuca, Petalonia fascia, Porphyra purpurea) or 2 to $4 \mathrm{~cm}$ apical shoots (Fucus serratus, Chondrus crispus). After 7 to $14 \mathrm{~d}$ acclimation, thallus pieces were grown at $7^{\circ} \mathrm{C}$ at 5 to 8 different light intensities and in the dark for 13 to $41 \mathrm{~d}$. The growth medium was GF/C filtered seawater enriched with $500 \mu \mathrm{g} \mathrm{NH}_{4}-\mathrm{N} \mathrm{l}^{-1}, 500 \mu \mathrm{g} \mathrm{NO} \mathrm{NO}_{3}-\mathrm{N}$ $\mathrm{l}^{-1}$ and $100 \mu \mathrm{g} \mathrm{PO}_{4}-\mathrm{Pl}^{-1}$. The experiment was repeated 6 times with 1 to 3 species each time. Growth rates ( $\mu$ ) were determined from changes in carbon content of the tissue over time $(t)$. Thallus specific carbon $(D)$ and dark respiration $\left(R_{\mathrm{d}}\right)$ were measured at the end of the experiments on all. thalli from the dark and from each light intensity. Dark respiration was measured as oxygen consumption in closed bottles over $14 \mathrm{~h}$ at $7^{\circ} \mathrm{C}$ and converted to carbon units assuming $\mathrm{RQ}$ of $0.8 \mathrm{~mol} \mathrm{CO}_{2}$ $\mathrm{mol}^{-1} \mathrm{O}_{2}$. Fractional light absorption $(A)$ was measured every week as 1 minus fractional transmission (Vermaat \& Sand-Jensen 1987) on all thalli.

The light compensation point was estimated from the relationship between growth rate and light (e.g. Fig. 1), by (1) selecting a light intensity below which the points show a linear relationship and then calculating $I_{c}$ by regression analysis, and (2) calculating the parameters for one of the common $\mu$-I or P-I functions

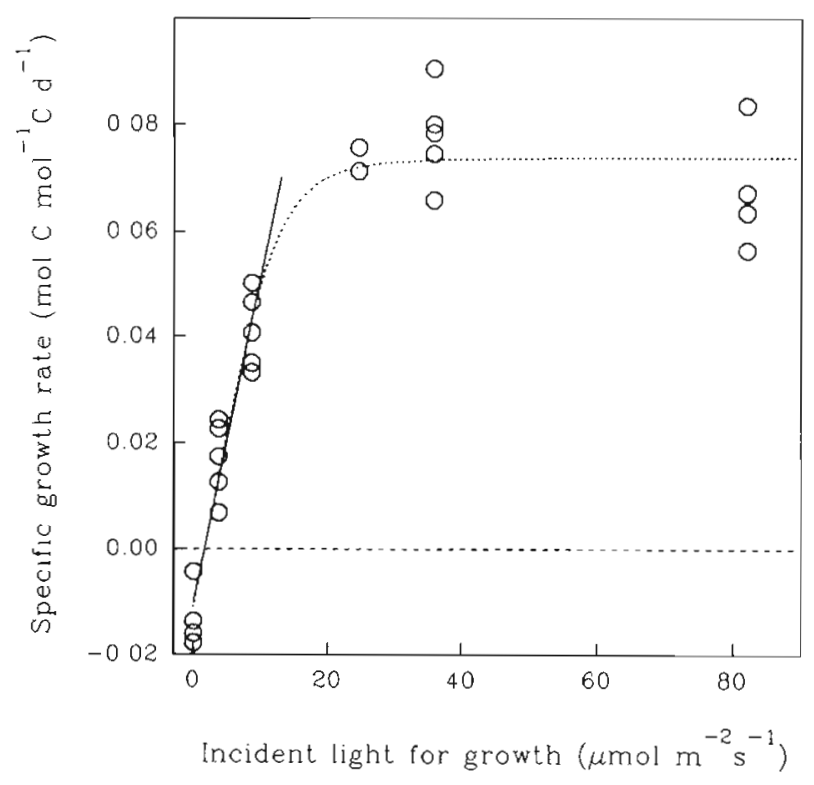

Fig. 1. Petalonia fascia. Specific growth rate vs incident light at $7^{\circ} \mathrm{C}$. (-) Linear relationship calculated by linear regression for points below $10 \mu \mathrm{mol} \mathrm{m} \mathrm{m}^{-2} \mathrm{~s}^{-1} ;(\cdots$.$) Eq. 1$ fitted to all data points

(Bannister 1979, Jassby \& Platt 1976) and then calculating $I_{c}$. Method 1 is objective, apart from the selection of the appropriate light range, and allows calculation of confidence limits for $I_{c}$. Method 2 seems objective, but the selection of $\mu$-I equation can bias the estimate of $I_{c}$ (Geider et al. 1985), and this method does not provide confidence limits for $I_{c}$. For Method 2 we used the equation of Bannister (1979) which has a shape parameter $(m)$ which should minimize the influence of curve shape on $I_{c}$ :

$$
\mu=\frac{\alpha I \mu_{m}}{\left(\left(\mu_{\mathrm{m}}\right)^{m}+(\alpha I)^{m}\right)^{1 / m}}+\mu_{\mathrm{d}}
$$

where $\mu=$ net growth rate; $\alpha=$ initial slope of growth rate vs light; $\mu_{\mathrm{m}}=$ maximal growth rate; and $\left(-\mu_{\mathrm{d}}\right)=$ loss rate in the dark. The difference between $I_{\mathrm{c}}$-values determined by the linear regression (Method 1) and the $\mu$-I curve (Method 2) was 0 to $1.2 \mu \mathrm{mol} \mathrm{m} \mathrm{m}^{-2} \mathrm{~s}^{-1}$ (mean value $0.35 \mu \mathrm{mol} \mathrm{m}^{-2} \mathrm{~s}^{-1}$ ) and 2.7 times less than the $95 \%$ confidence limits found by the linear regression method (mean values $\pm 0.95 \mu \mathrm{mol} \mathrm{m}{ }^{-2} \mathrm{~s}^{-1}$; Table 1). Thus, the uncertainty related to the choice of calculation method was small compared to the uncertainty of growth measurements of $I_{c}$. We subsequently chose the linear regression method because it provides confidence limits for $I_{c}$

Light-limited net growth rate of macroalgae with a flat thallus can be expressed by

$$
\mu=I \phi_{\mathrm{g}} A-\left(R_{\mathrm{m}}+k \mu_{\mathrm{g}}\right) D
$$

Symbols and units are defined in Table 1. The product $I \phi_{\mathrm{g}} A$ represents the area specific carbon gain per unit 
Table 1 . Observed and calculated light compensation points $\left(I_{c}, \mu \mathrm{mol} \mathrm{m}{ }^{-2} 5^{-1}\right)$ and the parameters that determine the calculated $I_{c}$ in different experiments with 5 species of marine macroalgae. Thallus specific carbon at $I_{\mathrm{c}}\left(D, \mathrm{~mol} \mathrm{C} \mathrm{m}^{-2}\right.$ thallus area, one side), weight specific dark respiration $\left(R_{\mathrm{m},} \mathrm{mmol} \mathrm{C} \mathrm{mol}{ }^{-1}\right.$ cell $\left.\mathrm{C} \mathrm{d}^{-1}\right)$, dark loss rates $\left(\mu_{\mathrm{d}}, \mathrm{mmol} \mathrm{C} \mathrm{mol}{ }^{-1}\right.$ cell $\left.\mathrm{C} \mathrm{d}^{-1}\right)$ and fractional light absorption ( $A$, dimensionless) are mean values of 10 to 14 individuals (Markager in press). Gross quantum yield for growth ( $\phi_{\mathrm{g}}$, mmol $\mathrm{C} \mathrm{mol}{ }^{-1}$ absorbed photons) is the mean value of individuals at limiting light (Markager in press). $k$ (dimensionless) $=$ slope of the linear relationship between parallel measurements of dark respiration and specific growth rate for 25 to 90 individuals. Thallus specific carbon and absorption at $I$, were calculated by interpolation between values in the dark and at low light. Area specific respiration at $I_{c}$ was calculated as $\left(R_{\mathrm{m}}+k \mu I_{\mathrm{i}}\right) \mathrm{D},\left(\mathrm{mmol} \mathrm{C} \mathrm{m}^{-2} \mathrm{~d}^{-1}\right)$. Photosynthetic efficiency $\left(\alpha^{\prime}\right)$ is calculated as $A \phi_{\mathrm{g}},\left[\mathrm{mmol}^{\mathrm{C}} \mathrm{Cm}{ }^{2} \mathrm{~d}^{-1}\right.$ $\left(\mu \mathrm{mol} \mathrm{m} \mathrm{m}^{-2} \mathrm{~s}^{-1}\right.$ ). CL: minimum estimates (see text) of confidence limits ( $p>0.95$ ); CV: coefficient of variation (SD/mean)

\begin{tabular}{|c|c|c|c|c|c|c|c|c|c|c|c|}
\hline \multirow[b]{2}{*}{ Light:dark cycle: } & \multicolumn{4}{|c|}{ Ulva lactuca } & \multicolumn{4}{|c|}{ Petalonia fascia } & \multirow{2}{*}{$\begin{array}{c}\text { Fucus } \\
\text { serratus } \\
14: 10\end{array}$} & \multirow{2}{*}{$\begin{array}{c}\text { Porphyra } \\
\text { purpurea } \\
24: 0\end{array}$} & \multirow{2}{*}{$\begin{array}{c}\text { Chondrus } \\
\text { crispus } \\
14: 10\end{array}$} \\
\hline & $24: 0$ & $24: 0$ & $14: 10$ & $24: 0^{\circ}$ & $24: 0$ & $24: 0$ & $14: 10$ & $14: 10$ & & & \\
\hline$\phi_{y}$ & 83 & 70 & 92 & 56 & 86 & 74 & 100 & 95 & 98 & 73 & 99 \\
\hline Absorption at $I_{c}$ & 0.63 & 0.63 & 0.65 & 0.40 & 0.58 & 0.60 & 0.59 & 0.68 & 0.89 & 0.48 & 0.88 \\
\hline$\alpha\left(\phi_{\mathrm{g}} \hat{A}\right)$ & 4.5 & 3.8 & 5.2 & 1.9 & 4.3 & 3.8 & 5.1 & 5.6 & 7.5 & 3.0 & 7.5 \\
\hline$D$ at $I_{c}$ & 0.46 & 0.59 & 0.58 & 0.36 & 0.30 & 0.45 & 0.35 & 0.35 & 2.46 & 0.38 & 4.38 \\
\hline Dark respiration & 6.0 & 5.1 & 3.5 & 13.0 & 24.0 & 21.6 & 18.6 & 30.6 & 2.7 & 2.9 & 0.47 \\
\hline Dark loss rate & 12.0 & 1.3 & 9.3 & 12.0 & 35.0 & 5.8 & 13.0 & 11.9 & 1.2 & 8.5 & 0.32 \\
\hline$k$ & 0.11 & 0.07 & 0.16 & 0.10 & 0.19 & -0.03 & 0.17 & 0.00 & 0.06 & 0.18 & 0.03 \\
\hline Respiration at $I_{c}$ & 3.3 & 3.0 & 2.9 & 5.1 & 9.0 & 9.7 & 7.2 & 10.7 & 6.8 & 1.7 & 2.1 \\
\hline Observed $I_{r}$ & 1.87 & 0.33 & 1.37 & 2.47 & 2.20 & 1.61 & 1.61 & 2.45 & 1.12 & 1.28 & 0.44 \\
\hline Calculated $I_{c}$ & 0.73 & 0.80 & 0.56 & 2.65 & 2.10 & 2.53 & 1.42 & 1.92 & 0.90 & 0.55 & 0.28 \\
\hline CL of observed $I_{c}$ & 0.3 & 1.73 & 1.35 & 0.97 & 1.21 & 1.50 & 0.89 & 1.02 & 3.55 & 0.89 & 6.75 \\
\hline CV of calculated $I_{\mathrm{c}}$ & - & 0.12 & 0.35 & - & - & 0.13 & 0.29 & 0.41 & 0.16 & - & 0.27 \\
\hline
\end{tabular}

time. The basic loss process is the carbon specific maintenance respiration $\left(R_{\mathrm{m}}\right)$, equivalent to the respiration of individuals kept in the dark for a long time. However, because the respiration rate increases linearly with the growth rate with the slope $k$ (Langdon 1988, Sand-Jensen 1988a, Geider \& Osborn 1989, Sand-Jensen \& Madsen 1991, Markager \& SandJensen unpubl.), the term $k \mu_{\mathrm{g}}$ is added to $R_{\mathrm{m}}$. Here $\mu_{\mathrm{g}}$ represents the gross growth rate defined as the observed growth rate $(\mu)$ plus the dark loss rate $\left(-\mu_{d}\right)$. To obtain the loss rate per unit area of the thallus, the carbon specific respiration rate is multiplied by the thallus specific carbon (D). Eq. 2 is rearranged to yield the light compensation point $\left(I_{c}\right)$ at zero growth $(\mu=0)$ :

$$
I_{c}=\frac{\left(R_{\mathrm{m}}-k \mu_{\mathrm{d}}\right) D}{\phi_{\mathrm{g}} A}
$$

For $\mu=0, \mu_{\mathrm{g}}$ is equal to the dark loss rate which is inserted in Eq. 3. $I_{\mathrm{C}}$-values calculated from Eq. 3 are hereafter denoted calculated $I_{\mathrm{c}}$-values and the $I_{\mathrm{c}}$-values estimated by linear regression from $\mu$-I plot are denoted observed values, because they (though calculated) are derived directly from measured growth rates.

Values for $R_{\mathrm{m}}$ and $\mu_{\mathrm{d}}$ were attained for individuals kept in the dark for at least $25 \mathrm{~d}$, and $k$ was determined from the relationship between respiration rate and growth rate for all individuals in each experiment. Gross quantum yield for growth $\left(\phi_{g}\right)$ was calcu- lated individually for each thalli from the increase in biomass $\left(x_{t}-x_{0}\right)$ and dark respiration $\left(R_{\mathrm{d}}\right)$, both converted to carbon units, and measurements of absorbed light $\left(I_{\mathrm{a}}\right)$

$$
\phi_{\mathrm{g}}=\frac{\left(x_{t}-x_{0}\right)+R_{\mathrm{d}} t}{l_{\mathrm{a}}}
$$

The measured values for absorbed light also include reflection and absorption by non photosynthetic active compounds, and the calculated $\phi_{\mathrm{g}}$-values, therefore, underestimate the true quantum yield (Markager in press). Quantum yield is known to decrease as the light intensity approaches saturation. Therefore, only values for light-limited individuals were used to calculate $\phi_{\mathrm{g}}$-values.

\section{RESULTS}

\section{Light compensation points}

Observed $I_{C}$-values were between 0.33 and $2.45 \mu \mathrm{mol} \mathrm{m} \mathrm{m}^{-2} \mathrm{~s}^{-1}$ and averaged 1.52 (Table 1). Three experiments with Ulva lactuca (a foliose green alga) yielded $0.33,1.37$ and $1.87 \mu \mathrm{mol} \mathrm{m} \mathrm{m}^{-2} \mathrm{~s}^{-1}$, slightly lower than $2.47 \mu \mathrm{mol} \mathrm{m}{ }^{-2} \mathrm{~s}^{-1}$ found by Sand-Jensen (1988a). In 4 experiments with the foliose brown alga Petalonia fascia, $I_{c}$-values were from 1.61 to 2.45 , and the 
$I_{\mathrm{c}}$-value was lower, $1.12 \mu \mathrm{mol} \mathrm{m} \mathrm{m}^{-2} \mathrm{~s}^{-1}$, for the leathery brown alga Fucus serratus. The foliose red alga Porphyra purpurea had an $I_{\mathrm{c}}$-value of $1.28 \mu \mathrm{mol} \mathrm{m}{ }^{-2} \mathrm{~s}^{-1}$ and the leathery red alga Chondrus crispus showed the lowest value of $0.44 \mu \mathrm{mol} \mathrm{m} \mathrm{m}^{-2} \mathrm{~s}^{-1}$. The small range (Table 1) means that none of the differences between species were statistically significant, given the uncertainty of the estimates.

The reported $I_{\mathrm{c}}$-values represent intensities during the light period. For Ulva lactuca and Petalonia fascia, where experiments were performed in continuous light or a 14:10 light:dark cycle, $I_{\mathrm{c}}$-values were relatively unaffected by the length of the light period (Table 1). Thus, the $24 \mathrm{~h}$ light dose to reach $I_{c}$ was lower for individuals kept in a light: dark cycle.

The $I_{\mathrm{c}}$-values calculated from Eq. 3 ranged from 0.28

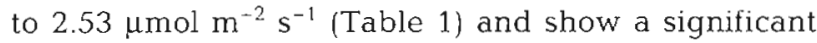
correlation $(\mathrm{r}=0.71, \mathrm{p}=0.013$; $t$-test $)$ to observed values (Fig. 2). Assuming that differences exceeding 2 SD are significant, Chondrus crispus has significantly lower calculated $I_{\mathrm{c}}$-values than Ulva lactuca and Fucus serratus in 1 experiment and than Petalonia fascia in 2 experiments.

\section{Regulation of $I_{\mathrm{c}}$}

Light absorption was higher in Fucus serratus and Chondrus crispus than in the other species with lower thallus specific carbon (Table 1). There was no signifi-

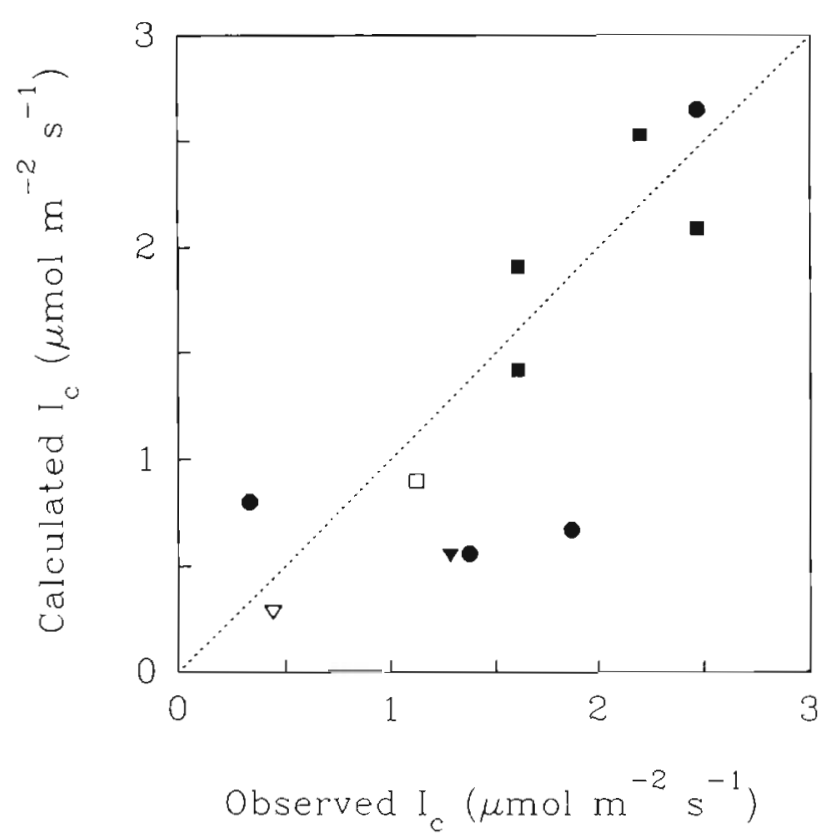

Fig. 2. Calculated (Eq. 3) versus observed values of the light compensation point for growth at $7^{\circ} \mathrm{C}_{i}(\bullet)$ Ulva lactuca; (a) Petalonia fascia; ( $\square$ ) Fucus serratus; $(\nabla)$ Chondrus crispus; ( $\mathbf{)}$ Porphyra purpurea cant difference in gross quantum yield between species. Mean dark respiration was high for Petalonia fascia (mean $23.8 \mathrm{mmol} \mathrm{C}$ mol cell $\mathrm{C}^{-1} \mathrm{~d}^{-1}$ ), intermediate for Ulva lactuca, F. serratus and Porphyra purpurea (2.7 to $6.0 \mathrm{mmol} \mathrm{C} \mathrm{mol} \mathrm{cell} \mathrm{C}^{-1} \mathrm{~d}^{-1}$ ) and low for C. crispus $\left(0.47 \mathrm{mmol} \mathrm{C} \mathrm{mol} \mathrm{cell} \mathrm{C}^{-1} \mathrm{~d}^{-1}\right)$. No systematic variations in $k$ and dark loss rate could be detected. However, for all 3 parameters $\left(R_{\mathrm{m}}, k\right.$ and $\left.\mu_{\mathrm{d}}\right)$ values were particularly low for $C$. crispus, indicating very low weight specific loss rates

We can identify the sensitivity of $I_{c}$ to variations in the parameters affecting $I_{c}$. Light absorption and quantum yield varied about 2 -fold among the 5 species whereas the 4 parameters affecting the area specific respiration rate varied 15 -fold or more (Table 2 ). The sensitivity of $I_{c}$ to variation of each parameter in Eq. 3 was calculated from the first partial derivative which has the unit $\mu \mathrm{mol} \mathrm{m} \mathrm{m}^{-2} \mathrm{~s}^{-1}$ (parameter unit) ${ }^{-1}$ (Table 2). The product of the first derivative and the range of variation for the specific parameter yields the potential contribution to the variation in $I_{c}$ caused by that parameter. We calculated the contribution to the variability in $I_{c}$ for the entire range of values observed in our experiments (Table 1). Calculations identified $D(60$ to $70 \%$ of the potential variation) and $R_{\mathrm{m}}$ (ca $25 \%$ of the variation in $I_{\mathrm{c}}$ ) as the main parameters influencing $I_{\mathrm{c}}$ (Table 3). Absorption and quantum yield had, because of low variability, negligible effects on $I_{c}$, and $I_{\mathrm{c}}$ was relatively unaffected by variations of $k$ and dark loss rate (Table 3 ). These results, based on the entire range observed for each parameter, refer to the total variability in $I_{c}$ for all 5 species. Within-species variability was, however, smaller than that among species particularly for $D$. Variability in $I_{c}$ was, for Ulva lactuca, mainly dependent on $R_{\mathrm{m}}$ and to a smaller extent on $A$ and $D$. For Petalonia fascia the main parameters controlling $I_{c}$ were $D$ and $R_{\mathrm{m}}$ (Table 3). The sum of variation in $I_{\mathrm{c}}$ for each parameter (Table 3 ) represents a maximum estimate of $I_{c}$ variability. Any positive relationship between gain $\left(A\right.$ and $\left.\phi_{g}\right)$ and loss parameters $\left(R_{\mathrm{m}}, \mu_{\mathrm{d}}, k\right.$ and $D$ ), or negative relations within gain or loss parameters, will reduce the actual variation in $I_{c}$. For the loss parameters we did find a negative correlation between $R_{\mathrm{m}}$ and $D$. Hence, the actual variation of areal specific respiration was smaller (6.3-fold) than the sum of variation in each of the loss parameters.

\section{DISCUSSION}

\section{Minimum light requirements}

Observed and calculated $I_{\mathrm{c}}$-values ranged between 0.3 and $2.7 \mu \mathrm{mol} \mathrm{m}^{-2} \mathrm{~s}^{-1}$ for the 5 species acclimated to low light at $7^{\circ} \mathrm{C}$. Because the species represent 
Table 2. First partial derivatives of the parameters in the equations for $I_{c}$ (Eq. 3 ) and the mean values for the 11 experiments in Table 1, using a $14: 10 \mathrm{~h} \mathrm{light} \mathrm{:} \mathrm{dark} \mathrm{cycle} \mathrm{for} \mathrm{all} \mathrm{experiments.} \mathrm{The} \mathrm{range} \mathrm{and} \mathrm{variability} \mathrm{of} \mathrm{the} \mathrm{parameters} \mathrm{are} \mathrm{given.} \mathrm{Units} \mathrm{as} \mathrm{in} \mathrm{Table} 1$

\begin{tabular}{|c|c|c|c|c|c|c|c|}
\hline Parameter & & $\frac{\mathrm{d} I_{\mathrm{c}}}{\mathrm{d} x}$ & $\begin{array}{l}\text { Mean of } \\
\text { 1st partial } \\
\text { derivative }\end{array}$ & Minimum & Maximum & Range & $\begin{array}{l}\text { Factor of } \\
\text { variation }\end{array}$ \\
\hline Quantum yield & $\frac{\mathrm{d} I_{c}}{\mathrm{~d} \phi}$ & $=-\frac{\left(R_{\mathrm{m}}-k \mu_{\mathrm{d}}\right) D}{A \phi^{2}}$ & -0.029 & 56 & 100 & 44 & 1.8 \\
\hline Absorption & $\frac{\mathrm{d} I_{\mathrm{c}}}{\mathrm{d} A}$ & $=-\frac{\left(R_{\mathrm{m}}-k \mu_{\mathrm{d}}\right) D}{A^{2} \phi}$ & -3.97 & 0.40 & 0.89 & 0.49 & 2.2 \\
\hline Thallus specific carbon & $\frac{\mathrm{d} I_{c}}{\mathrm{~d} D}$ & $=\frac{\left(R_{\mathrm{m}}-k \mu_{\mathrm{d}}\right)}{A \phi}$ & 5.52 & 0.295 & 4.38 & 4.09 & 14.9 \\
\hline Dark respiration & $\frac{\mathrm{d} I_{\mathrm{c}}}{\mathrm{d} R_{\mathrm{m}}}$ & $=\frac{D}{A \phi}$ & 0.297 & 0.47 & 30.6 & 30.1 & 65.1 \\
\hline$k$ & $\frac{\mathrm{d} I_{\mathrm{C}}}{\mathrm{d} k}$ & $=\frac{\mu_{\mathrm{d}} D}{A \phi}$ & 1.72 & -0.03 & 0.19 & 0.22 & $\infty$ \\
\hline Dark loss rate & $\frac{\mathrm{d} I_{\mathrm{c}}}{\mathrm{d} \mu_{\mathrm{d}}}$ & $=\frac{k D}{A \phi}$ & 0.021 & 0.32 & 35.0 & 34.7 & 109 \\
\hline
\end{tabular}

different taxonomic groups and thallus thicknesses, this interval may, overall, be a realistic range for foliose and leathery marine macroalgae grown at $7^{\circ} \mathrm{C}$ Literature data for these thallus types support this conclusion. Values between 2.2 and $3.3 \mu \mathrm{mol} \mathrm{m} \mathrm{m}^{-2} \mathrm{~s}^{-1}$ in Ascophyllum nodosum and Pelvetia canaliculata can be calculated from growth data $\left(10^{\circ} \mathrm{C}\right)$ presented by Schonbeck \& Norton (1980). Chapman \& Lindley (1980) found $0.64 \mu \mathrm{mol} \mathrm{m} \mathrm{m}^{-2} \mathrm{~s}^{-1}\left(0\right.$ to $\left.1^{\circ} \mathrm{C}\right)$ in Laminaria solidungula and Maggs \& Guiry (1987) obtained very low values $\left(0.2 \mu \mathrm{mol} \mathrm{m} \mathrm{m}^{-2} \mathrm{~s}^{-1}, 15^{\circ} \mathrm{C}\right)$ for a filamentous

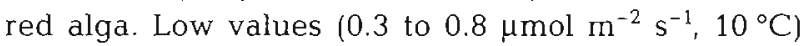

were also found for 3 Laminaria species and Saccorhiza polyschides (Kain 1966). However, some of these values may be underestimated because they are based on changes in surface area or fresh weight. Some species are able to increase their area or fresh weight at low light and in the dark, at the expense of their carbon reserves (Chapman \& Lindley 1980, SandJensen 1988a, Markager \& Sand-Jensen unpubl.).

Reported $I_{c}$-values for photosynthesis are usually higher than $I_{c}$-values for growth. Mean values for 22 species of marine macroalgae were $6.2 \mu \mathrm{mol} \mathrm{m} \mathrm{m}^{-2} \mathrm{~s}^{-1}$ at $5^{\circ} \mathrm{C}$ and $7.7 \mu \mathrm{mol} \mathrm{m} \mathrm{m}^{-2} \mathrm{~s}^{-1}$ at $10^{\circ} \mathrm{C}$ (King \& Schramm

Table 3. Mean values of the product $\mathrm{d} I_{\mathrm{c}} / \mathrm{d} x\left(x_{\max }-x_{\min }\right)\left(\mathrm{d} I_{\mathrm{c}} / \mathrm{d} x=\right.$ mean of the first partial derivative; and $\left(x_{\max }-x_{\min }\right)=$ range of the parameter for individuals grown at $I_{c}$ ) for the 6 parameters in Eq. 3. Values are shown for all experiments together, for 4 experiments with Ulva lactuca, and for 4 experiments with Petalonia fascia. Units are $\mu \mathrm{mol} \mathrm{m}^{-2} \mathrm{~s}^{-1}$

\begin{tabular}{|c|c|c|c|c|c|c|}
\hline \multirow[t]{2}{*}{ Parameter } & \multicolumn{2}{|c|}{ All experiments } & \multicolumn{2}{|c|}{ Ulva lactuca } & \multicolumn{2}{|c|}{ Petalonia fascia } \\
\hline & Mean & $\begin{array}{l}\% \text { of sum } \\
\text { of means }\end{array}$ & Mean & $\begin{array}{l}\% \text { of sum } \\
\text { of means }\end{array}$ & Mean & $\begin{array}{l}\% \text { of sum } \\
\text { of means }\end{array}$ \\
\hline Quantum yield $\left(\phi_{\mathrm{g}}\right)$ & -0.11 & 0.32 & -0.10 & 2.0 & -0.09 & 2.0 \\
\hline Absorption & -1.94 & 5.6 & -1.06 & 21.4 & -0.56 & 12.4 \\
\hline Thallus specific carbon & 22.58 & 65.1 & 1.12 & 22.5 & 1.51 & 33.5 \\
\hline Dark respiration & 8.94 & 25.8 & 2.25 & 45.2 & 1.63 & 36.3 \\
\hline$k$ & 0.38 & 1.1 & 0.18 & 3.6 & 0.44 & 9.9 \\
\hline Dark loss rate & 0.74 & 2.1 & 0.27 & 5.4 & 0.26 & 5.9 \\
\hline Sum of absolute values & 34.7 & 100.0 & 4.97 & 100.0 & 4.50 & 100.0 \\
\hline
\end{tabular}


1976). Dunton \& Jodwalis (1988) estimated $I_{\mathrm{c}}$ for photosynthesis to be about $3 \mu \mathrm{mol} \mathrm{m} \mathrm{m}^{-2} \mathrm{~s}^{-1}$ in Laminaria solidungula $\left(2^{\circ} \mathrm{C}\right)$ and Matta \& Chapman (1991) found $26.3 \mu \mathrm{mol} \mathrm{m} \mathrm{m}^{2} \mathrm{~s}^{-1}$ in Colpomenia peregrina 15 to $20^{\circ} \mathrm{C}$ ). Apart from methodological differences, a possible explanation for the discrepancy is that respiration rates increase with growth rates (Langdon 1988, SandJensen 1988b, Markager \& Sand-Jensen unpubl.). $I_{\mathrm{c}^{-}}$ values obtained in photosynthesis experiments with plants grown at normal light intensities (King \& Schramm 1976, Matta \& Chapman 1991) will, therefore, be higher than $I_{c}$-values for growth with plants acclimated to low light conditions (Sand-Jensen 1988b). Consequently, photosynthetic measurements of $I_{c}$ do not allow estimates of minimum light requirements for growth and maximum depth penetration, unless experiments are performed with individuals acclimated to light intensities about the $I_{c}$-value. This aspect is frequently overlooked.

\section{Factors affecting minimum light requirements}

The $I_{\mathrm{c}}$-model (Eq. 3) is a combination of well-known relationships between light intensity and carbon gain, and between growth rate and respiration. The model is able to explain most of the variation in the observed $I_{c^{-}}$ values, despite the large confidence limits relative to the small range of $I_{\mathrm{c}}$-values. Furthermore, no systematic deviation from a 1:1 relationship was found (Fig. 2) and the mean values were in close agreement. Hence, the model developed here should provide a useful basis for the analysis of variations in $I_{\mathrm{C}}$.

The sensitivity analysis showed that the 9-fold variation in $I_{\mathrm{c}}$ observed over the 11 experiments (Table 1) was primarily attributable to differences in weight specific dark respiration rate and thallus specific carbon whereas the influence of light absorption and quantum yield was much smaller. To appreciate this difference in variability of gain and loss processes of organic carbon, we must consider the physical constraints on the parameters.

The gain parameters ( $A$ and $\phi$ ) have well defined upper limits ( 1 for $A$ and $125 \mathrm{mmol} \mathrm{C} \mathrm{mol}{ }^{-1}$ photons for ф; Raven 1984j, and the observed values are within about $50 \%$ of these values and consequently vary less than 2 -fold. For quantum yield the differences between the observed and the theoretical values were mainly due to reflection and absorption by structural components (Markager in press). Furthermore, all values below $92 \mathrm{mmol} \mathrm{C} \mathrm{mol}{ }^{-1}$ photons were found in experiments with continuous light suggesting that this represents a stress which reduces quantum yield. We therefore conclude that about $95 \mathrm{mmol} \mathrm{C} \mathrm{mol}{ }^{-1}$ photons is a realistic value for all species in a natural light cli- mate. A detailed analysis of quantum yield for growth for the species treated here is provided by Markager (in press). Light absorption varies more than quantum yield but was closely correlated with the log thallus specific carbon (Markager in press), probably because absorption in thin species is limited by the maximum possible pigment content per unit area (Markager in press) and package effects (Rabinowitch 1951, Britz \& Briggs 1987). Overall, carbon gain in individuals adapted to low light is close to the maximum attainable provided that nutrients and growth conditions otherwise are adequate. The low values for absorption and quantum yield for UIva lactuca included in Table $1\left(A=0.4, \phi_{\mathrm{g}}=56 \mathrm{mmol} \mathrm{C}\right.$ $\mathrm{mol}^{-1}$ photons) from Sand-Jensen $(1988 \mathrm{a}, \mathrm{b})$ are presumably due to nitrogen limitation and high light levels in the field at collection of plants for experiments.

The carbon specific respiration rate varied considerably, and in contrast to the upper limits for $A$ and $\phi$, the physical constraints on lower limits of $R_{\mathrm{m}}$ are not quantified in the literature. Consequently, we are unable to determine a theoretical lower limit for $I_{c}$, Fucus serratus, Chondrus crispus and Porphyra purpurea had low rates of dark respiration which, in $C$. crispus, more than compensated for the high thallus specific carbon. C. crispus and $P$. purpurea had the lowest area specific respiration rates among the 5 species. If this is a general phenomenon among red algae, it could explain their common dominance at great depths (Sears \& Cooper 1978, Dring 1981, Mathieson et al. 1981), but further experiments are needed to test this hypothesis.

\section{Experimental $I_{\mathrm{c}}$-values and depth limits}

Subtidal vegetation of macroalgae can be divided into 3 zones (Vadas \& Steneck 1988). An uppermost zone dominated by large brown algae with an understorey of other algae; an intermediate zone where foliose and delicately-branched species dominate, still with an understorey of crustose algae; and a deep community where vegetation consists only of crustose, often calcified algae (Norton et al. 1977, Littler et al. 1985, Vadas \& Steneck 1988). The vertical extension of these zones is set by light attenuation in the water column and is, therefore, best described by the percent of surface light (\% SI) reaching their maximum depth of growth. Reported extinction depths for these 3 zones range from 0.12 to $1.5 \%$ SI (mean $0.48 \%$ SI) for the upper zone, where large brown algae dominate, from 0.02 to $0.22 \% \mathrm{SI}$ (mean $0.12 \%$ SI) for that dominated by foliose algae, and from 0.003 to $0.05 \%$ SI (mean $0.012 \%$ SI) for the deepest zone dominated by crustose algae, with the extremely low values of $0.0005 \%$ SI (Littler et al. 1985) and $0.00023 \%$ SI (Agegian \& Abbott 1985) as apparent 
exceptions (Table 4). The value of Littler et al. (1985) was found by extrapolation of a light attenuation curve between 0 and $120 \mathrm{~m}$ (Fig. 1 in Littler et al. 1986) down to $268 \mathrm{~m}$ and Agegian \& Abbott (1985) only provided a mean attenuation coefficient of $0.052 \mathrm{~m}^{-1}$ for the entire water column. Direct light measurements are needed to confirm the exact light levels as \% SI for these deepest records of macroalgae.

If these depth limits corresponded to a fixed light dose, then depth limits as \% SI are expected to be shallower at higher latitudes due to less incoming surface light. This expectation is not supported by the data (Table 4) for leathery and foliose algae. In fact, the deepest growing large brown algae were found in the arctic (Chapman \& Lindley 1980, Dunton 1990), where the annual light dose at the maximum depth of Laminaria solidungula was 45 to $50 \mathrm{~mol} \mathrm{~m}^{-2} \mathrm{yr}^{-1}$ (Dunton 1990), which is lower than $71 \mathrm{~mol} \mathrm{~m}^{-2} \mathrm{yr}^{-1}$ for Laminaria hyperbora at Helgoland (North Sea) (Lüning \& Dring 1979). Perhaps reduced metabolic rates associated with lower temperature at higher latitudes compensate for the lower surface light there, so that depth limits, given as \% $\mathrm{SI}_{\text {, are relatively }}$ independent of latitude. Data for crustose species from temperate and especially from arctic regions are needed before a general statement can be made for this group.
Our experimental $I_{\mathrm{c}}$-values $\left(0.3\right.$ to $\left.2.5 \mu \mathrm{mol} \mathrm{m} \mathrm{m}^{-2} \mathrm{~s}^{-1}\right)$ in a $14: 10$ h light: dark cycle correspond to 5.5 to $46 \mathrm{~mol}$ $\mathrm{m}^{-2} \mathrm{yr}^{-1}$ or about 0.12 to $0.61 \% \mathrm{SI}$ in Denmark $\left(56^{\circ} \mathrm{N}\right)$, where mean water temperatures are close to the experimental temperature $\left(7^{\circ} \mathrm{C}\right)$. These values agree with \% SI values in Table 4 for leathery and foliose algae. The correspondence suggests that algae living at depths with $\% \mathrm{SI}$ in the lower part of the ranges in Table 4 have no surplus energy to cover grazing or mechanical losses. This is supported by observations of particularly deep growth when grazing is insignificant. For example, Vadas \& Steneck (1988) found lower depth limits $(0.4 \%$ SI) for large brown algae when herbivores were few, which is lower than that reported for Laminaria hyperbora $(1.5 \% \mathrm{SI})$ on a location subjected to grazing by Echinus esculentus (Kain 1971, 1976). It therefore appears that the greatest depth limits in Table 4 are set directly by the physiological light compensation point for growth.

\section{Thallus-specific carbon influencing macroalgal zonation}

Vertical distribution of macroalgae in the 3 zones as proposed by Vadas \& Steneck (1988) is supported by

Table 4. Depth limits of marine macroalgae with sheet-like thalli in metres and in percent of surface light (\% SI) for localities from tropical to high arctic northern regions. Species are divided into 3 morphological types. Leathery species have a thick thallus with many cell-layers and foliose species have a thin thallus with only one or few cell-layers. In cases where the reference listed depth limits for many species, only the deepest occurring species in each group was included

\begin{tabular}{|c|c|c|c|c|c|c|}
\hline Species & $\begin{array}{c}\text { Latitude } \\
\left({ }^{\circ} \mathrm{N}\right)\end{array}$ & $\begin{array}{l}\text { Depth } \\
(\mathrm{m})\end{array}$ & $\begin{array}{c}\text { Leathery } \\
(\% \mathrm{SI})\end{array}$ & $\begin{array}{c}\text { Foliose } \\
\text { (\% SI) }\end{array}$ & $\begin{array}{c}\text { Crustose } \\
(\% \mathrm{SI})\end{array}$ & Source \\
\hline Cystoseira sp. & 27 & 8.5 & 0.2 & & & Neushul (1971) \\
\hline Cystoseira sp. & 28 & 9.5 & 0.12 & & & Neushul (1971) \\
\hline Agarum cribrosum & 43 & 40 & 0.44 & & & Vadas \& Steneck (1988) \\
\hline Laminaria hyperborea & 54 & 8 & 0.7 & & & Lüning \& Dring (1979) \\
\hline Laminaria hyperborea & 54 & 19 & $1.0-1.9$ & & & Kain (1971), Kain et al. (1976) \\
\hline Laminaria solidungula & 70 & 6.4 & 0.2 & & & Dunton (1990) \\
\hline Laminaria solidungula & 69 & 20 & 0.18 & & & Chapman \& Lindley (1980) \\
\hline Foliose macroalgae & 11 & 140 & & 0.18 & & Hillis-Colinvaux (1985), Colin et al. (1986) \\
\hline Lobophora variegata & 16 & 140 & & 0.06 & & Agegian \& Abbott (1985) \\
\hline Monostroma sp. & 21 & 118 & & 0.22 & & Agegian \& Abbott (1985) \\
\hline Johnson-Sea-linkia profunda & 24 & 157 & & 0.02 & & Littler et al. (1985) \\
\hline Maripelta sp. & 28 & 13 & & 0.12 & & Neushul (1971) \\
\hline Ptilota serrata & 43 & 50 & & 0.11 & & Vadas \& Steneck (1988) \\
\hline Phycodrys rubens & 43 & 50 & & 0.11 & & Vadas \& Steneck (1988) \\
\hline Corallines & 11 & 228 & & & 0.004 & Hillis-Colinvaux (1985), Colin et al. (1986) \\
\hline Crustose red algae & 16 & 250 & & & $0.00023^{\circ}$ & Agegian \& Abbott $(1985)$ \\
\hline Crustose red algae & 21 & 182 & & & 0.008 & Agegian \& Abbott (1985) \\
\hline Crustose red algae & 24 & 268 & & & 0.0005 & Littler et al. (1985) \\
\hline Crustose red algae & 36 & Cave & & & 0.003 & Larkum et al. (1967) \\
\hline Leptophytum laeve & 43 & 63 & & & 0.02 & Vadas \& Steneck (1988) \\
\hline Lithothamnion $\mathrm{sp}$. & 54 & 15 & & & 0.05 & Lüning \& Dring (1979) \\
\hline Overall mean & & & 0.48 & 0.12 & 0.012 & \\
\hline
\end{tabular}


the data in Table 4. Algal growth forms in these zones correspond to 3 levels of thallus specific carbon $(D)$. $D$-values between 1.5 and $4.5 \mathrm{~mol} \mathrm{C} \mathrm{m}^{-2}$ are representative for leathery species, e.g. Fucus or Laminaria species and Chondrus crispus (Lüning 1971, 1979, Raven et al. 1979, this study). The foliose species in this study had $D$-values between 0.3 and $0.6 \mathrm{~mol} \mathrm{C} \mathrm{m}^{-2}$ at $I_{C}$, representative for 'thin algae', and the density of the deepest crustose algae in Littler et al. (1985) can be calculated to be $0.0087 \mathrm{~mol} \mathrm{C} \mathrm{m}^{-2}$ (Littler et al. 1986).

Thallus specific carbon (D) regulates the area specific growth rate in 2 ways. Together with the carbon specific respiration $(R)$ it affects the area specific respiration $\left(R_{a}=R D\right)$ which, as shown above, is a keyfactor for the carbon balance per unit area and thus for $I_{C}$. However, $D$ also regulates the specific gross growth rate [net growth plus respiratory losses, mol C (mol cell $C)^{-1} d^{-1}$ ] attainable for a certain carbon surplus per unit area. Though light absorption, and thereby carbon fixation, increases to some extent with $D$ (Markager in press), the specific gross growth rate will decline in direct proportion to $D$ for a constant carbon fixation rate per unit area. This is the situation because the variation in $D$ is much larger (15-fold in this experiment) than the variation in light absorption

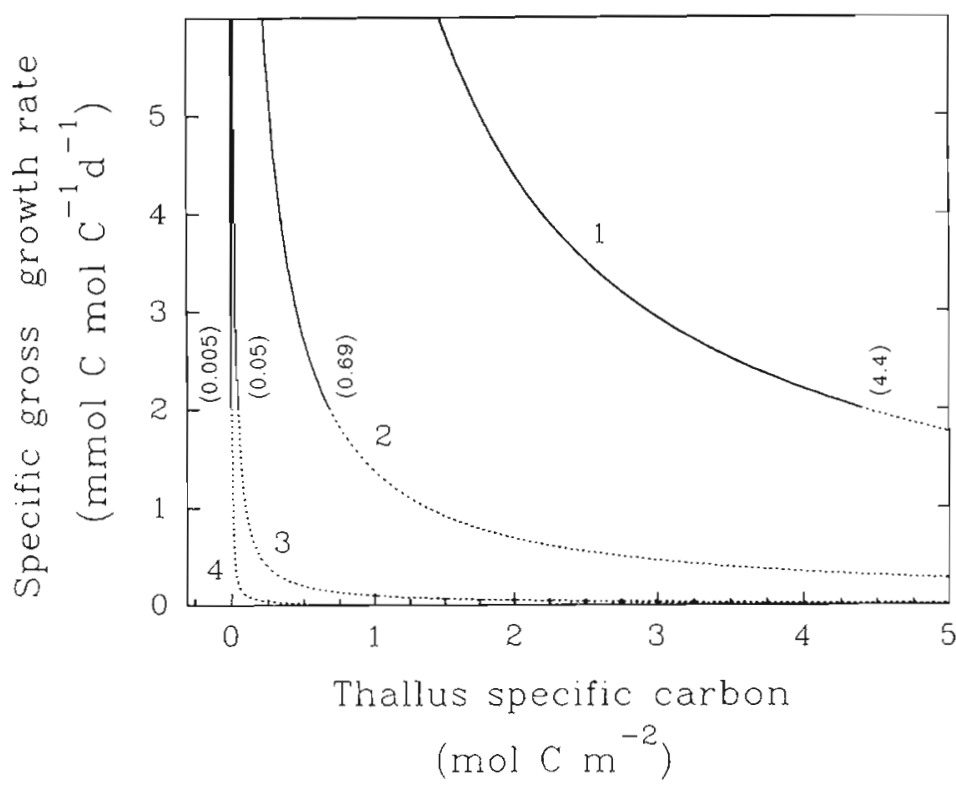

Fig. 3. Relationship between thallus specific carbon and specific gross growth rate at 4 combinations of light intensity and absorption. (1) A leathery alga living at $0.5 \% \mathrm{SI}$, light absorption $=0.9 ;(2) \mathrm{A}$ foliose alga living at $0.10 \% \mathrm{SI}$, light absorption $=0.7 ;(3) \mathrm{A}$ crustose algae living at $0.01 \% \mathrm{SI}$, light absorption $=0.5$; (4) A crustose alga living at $0.0005 \%$ SI, light absorption $=0.45$. Mean surface light (SI) was $238 \mu \mathrm{mol} \mathrm{m}^{-2} \mathrm{~s}^{-1}$ in examples 1 to 3 corresponding to Danish conditions $\left(56^{\circ} \mathrm{N}\right)$ and $550 \mu \mathrm{mol} \mathrm{m} \mathrm{m}^{-2} \mathrm{~s}^{-1}$ in example 4 corresponding to conditions at Bahamas Islands $\left(24^{\circ} \mathrm{N}\right)$. Quantum yield was in all cases assumed to be $95 \mathrm{mmol}$ $\mathrm{C} \mathrm{mol}^{-1}$ absorbed photons. The thallus specific carbon where gross growth rate drops below $2 \mathrm{mmol} \mathrm{C} \mathrm{mol}^{-1}$ cell $\mathrm{C} \mathrm{d}^{-1}$ is indicated (2-fold here). Therefore, macroalgae will show an inverse relationship between light limited gross growth rate and $D$ as depicted in the 4 examples in Fig. 3. For leathery algae (1, Fig. 3) growing to a maximum depth of $0.5 \% \mathrm{SI}$, calculated gross growth rate approaches $2 \mathrm{mmol} \mathrm{C} \mathrm{mol}{ }^{-1} \mathrm{C} \mathrm{d}^{-1}$ when the thallus specific carbon reaches $4.4 \mathrm{~mol} \mathrm{C} \mathrm{m} \mathrm{C}^{-2}$ This gross growth rate exceeds dark respiration rates in some thick species and allows a low, but not unrealistic, specific growth rate. For example, the dark respiration rate of Chondrus crispus was only $0.5 \mathrm{mmol} \mathrm{C} \mathrm{mol}^{-1} \mathrm{C}$ $\mathrm{d}^{-1}$. For an alga living at $0.10 \%$ SI (2, Fig. 3) a thallus specific carbon content of $4.4 \mathrm{~mol} \mathrm{C} \mathrm{m}^{-2}$, however, will provide an unacceptable low growth rate. The $D$-value yielding a gross growth rate of $2 \mathrm{mmol} \mathrm{C} \mathrm{mol}^{-1} \mathrm{C} \mathrm{d}^{-1}$ is $0.69 \mathrm{~mol} \mathrm{C} \mathrm{m} \mathrm{C}^{-2}$ at this \% SI. At even lower light, e.g. $0.01 \%$ SI (3, Fig. 3), $D$ must be lower than $0.05 \mathrm{~mol}$ $\mathrm{C} \mathrm{m} \mathrm{m}^{-2}$ before gross growth rate exceeds $2 \mathrm{mmol} \mathrm{C}$ $\mathrm{mol}^{-1} \mathrm{C} \mathrm{d}^{-1}$. The upper level of $D$-values in 1 and 2 (Fig. 3) corresponds to that for leathery and foliose algae found in this study. A D-value of $0.05 \mathrm{~mol} \mathrm{C} \mathrm{m}-2$ for crustose algae is higher than the value calculated from Littler et al. (1986), which, however, represents an exceptionally deep living species. At higher light levels crustose algae may be thicker, such as Peysonellia sp. (a fleshy crustose algae) found to have its depth limit above the deepest occurring calcified crustose red algae (Agegian \& Abbott 1985, Littler et al. 1985). Other data for thallus specific carbon in crustose macroalgae are not available. The last curve (4, Fig. 3) is for an alga living at great depths with only $0.0005 \%$ SI at a latitude receiving a mean light intensity of $550 \mu \mathrm{mol} \mathrm{m}^{-2} \mathrm{~s}^{-1}$ at the sea surface $\left(24^{\circ} \mathrm{N}\right)$, the conditions for the deepest occurring crustose in Littler et al. (1985). This species should, for a $D$-value of $0.0087 \mathrm{~mol} \mathrm{C} \mathrm{m} \mathrm{m}^{-2}$, be able to attain a gross growth rate of $1.2 \mathrm{mmol} \mathrm{C} \mathrm{mol}^{-1} \mathrm{C} \mathrm{d}^{-1}(\mathrm{ab}$ sorption by photosynthetic active pigments assumed to be 0.45 and quantum yield to be $95 \mathrm{mmol} \mathrm{C} \mathrm{mol}^{-1}$ photons). Dark respiration of this species must, therefore, be very low. Assuming a dark respiration rate as for $C$. crispus in this experiment $\left(0.5 \mathrm{mmol} \mathrm{C} \mathrm{mol}^{-1}\right.$ $\mathrm{C} \mathrm{d}^{-1}$ ) the net growth rate will be $0.7 \mathrm{mmol}$ $\mathrm{mol}^{-1} \mathrm{C} \mathrm{d}^{-1}$ corresponding to a generation time of 3 yr. Survival at such a low growth rate is only possible in a stable environment with practically no grazing achieved by thallus calcification or lack of grazers.

The examples in Fig. 3 are based on the different morphological types, their mean depth limits obtained from Table 4 and realistic values for absorption and quantum yield from 
Table 1. Values for $D$, where gross growth rates drop below $2 \mathrm{mmol} \mathrm{C} \mathrm{mol}^{-1} \mathrm{C} \mathrm{d}^{-1}$ are indicated. This level of gross growth rate allows a low positive net growth for species with a dark loss rate corresponding to the lowest experimentally derived dark respiration rates in Table 1 . The indicated $D$-values are the maximum possible in each case, but for leathery and foliose algae, they correspond to measured values of $D$ for these groups. We therefore conclude that Fig. 3 provides a realistic picture of possible combinations of depth limits, respiratory losses and net growth rates of marine macroalgae at low light.

The curves in Fig. 3 predict that thin thalli (i.e. low thallus specific carbon) ensure higher specific growth rates at light limitation than thick thalli. The crustose life form represents the most extreme adaptation and the most suitable multicellular thallus with low thallus specific carbon. Thick thalli, on the other hand, provide several advantages at high light such as greater mechanical strength, ability to form a canopy and shade-out competitors, better possibility for differentiation of cells and storage of carbohydrates and nutrients as exemplified by Laminaria species (Lüning 1971, Chapman \& Lindley 1980j. Thallus specific carbon, therefore, becomes an important part of the physiological features regulating vertical zonation and growth strategies of subtidal marine macroalgae. Low growth rate at low light also means that deep-living algae need long time to form the biomass. Accordingly, the proportion of perennial species increases with depth (Mathieson 1979).

In Danish coastal regions Porphyra purpurea and the erect form of Petalonia fascia only grow in shallow water $(0$ to $1.5 \mathrm{~m})$ whereas the other 3 species occur in most of the subtidal zone with erect macroalgal vegetation except for the deepest parts where vegetation is dominated by Phycodrys rubens and Delesseria sanguinea. Because the 5 species had approximately the same light requirements for survival in our laboratory experiments the differences in depth-zonation must be related to their growth form/strategy. Porphyra purpurea and Petalonia fascia are probably restricted to very shallow water due to their annual lifecycle and Fucus serratus and Chondrus crispus are probably excluded from the deepest parts due to their thick thallus. However, additional experiments are needed on the physiology of particularly deep-living species and on actual loss rates in the field for different species, to further evaluate the parameters that determine macroalgal depth zonation.

We conclude that macroalgal growth and survival in low light require high photosynthetic efficiency at low light, low dark respiration rate, low thallus specific carbon, resistance against grazing, and possibly a perennial life cycle. High quantum yield and high photosynthetic efficiency seem to be common among most species. Dark respiration rates, on the other hand, can vary over 2 orders of magnitude $(0.5$ to $30 \mathrm{mmol} \mathrm{C}$ $\mathrm{mol}^{-1} \mathrm{C} \mathrm{d}^{-1}$, half-life of the carbon content at 1386 and $23 \mathrm{~d}$ respectively) but even at the lowest respiration rates, low thallus specific carbon (i.e. a thin thallus) is essential for growth at low light.

Acknowledgements. This work was supported by the Danish Natural Science Research Council grant 11-7795 to the project: 'Structural and ecophysiological adaptations of macrophytes to ecological conditions in the transition between aerial and submerged life' and grant 11-7139 to S.M. We thank T. Lieu, H. Nielsen and S. Siune for technical assistance, T. Madsen B. Olesen, H.-H. Schierup and K. Skovhus for valuable discussions, L. Mathiesen for help with collection and identification of the species and $C$. M. Duarte for valuable comments to the manuscript.

\section{LITERATURE CITED}

Agegian, C. R., Abbott, I. A. (1985). Deep water macroalgal communities: a comparison between Penguin Bank (Hawaii) and Johnston Atoll. In: Gabriele, C., et al. (eds.) Proc. 5th Int. Coral Reef Congr. Antenne Museum - EPHE, Moorea, French Polynesia, 5: 47-50

Bannister, T T (1979). Quantitative description of steady state, nutrient-saturated algal growth, including adaption Limnol. Oceanogr. 24: 76-96

Britz, S. J., Briggs, W. R. (1987). Chloroplast movement and light transmission in Ulva: The sieve effect in a lightscattering system. Acta Physiol. Plant. 9: 149-162

Chapman, A. R. O., Lindley, J. E. (1980). Seasonal growth of Laminaria solidungula in the Canadian High Arctic in relation to irradiance and dissolved nutrient concentrations. Mar. Biol. 57: 1-5

Colin, P. L., Devaney, D. M., Hillis-Colinvaux, L., Suchanek, T H., Harrison, J. T. (1986). Geology and biological zonation of the reef slope, $50-360 \mathrm{~m}$ depth at Enewetak Atoll Marshall Islands. Bull. mar. Sci. 38: 111-128

Dring, M. J. (1981). Chromatic adaptation of photosynthesis in benthic marine algae: an examination of its ecological significance using a theoretical model. Limnol. Oceanogr 26: $271-284$

Dunton, K. H. (1990). Growth and production in Laminaria solidungula: relation to continuous underwater light levels in the Alaskan High Arctic. Mar. Biol. 106: 297-304

Dunton, K. H., Jodwalis, C. M. (1988). Photosynthetic performance of Laminaria solidungula measured in situ in the Alaskan High Arctic. Mar. Biol. 98: 277-285

Geider, R. J., Osborne, B. A. (1989). Respiration and microalgal growth: a review of the quantitative relationship between dark respiration and growth. New Phytol. 112 $327-341$

Geider, R. J., Osborne, B. A., Raven, J. A. (1985). Light dependence of growth and photosynthesis in Phaeodactylum tricornutum (Bacillariophyceae). J. Phycol. 21: $609-619$

Hillis-Colinvaux, L. (1985). Halimeda and other deep forereef algae at Enewetak Atoll. Proc. 5th Int. Coral Reef Cong., Tahiti, p. 9-14

Jassby, A. D., Platt, T. (1976). Mathematical formulation of the relationship between photosynthesis and light for phytoplankton. Limnol. Oceanogr. 21: 540-547 
Kain, J. M. (1966). The role of light in the ecology of Laminaria hyperborea. In: Bambridge, R., Clifford, G. Rackham, O. (ed.) Light as an ecological factor. Blackwell, Oxford, p. 319-334

Kain, J. M. (1971). Continuous recording of underwater light in relation to Laminaria distribution. In: Crisp, D. J. (ed.) Proc. 4th Eur. mar. Biol. Symp. Cambridge Univ. Press, London, p. 335-346

Kain, J. M. (1976). The biology of Laminaria hyperborea. Oceanogr. mar. Biol. A. Rev. 17: 101-161

Kain, J. M., Drew, E. A., Jupp., B. P. (1976). Light and the ecology of Laminaria hyperborea II. In: Evans, G. C., Bainbridge, R., Rackham, O. (eds.) Light as an ecological factor. Blackwell, Oxford, p. 63-92

King, R. J., Schramm, W. (1976). Photosynthetic rates of benthic marine algae in relation to light intensity and seasonal variations. Mar. Biol. 37: 215-222

Langdon, C. (1988). On the causes of interspecific differences in the growth-irradiance relationship for phytoplankton. II. A general review. J. Plankton. Res. 10: 1291-1312

Larkum, A. W. D., Drew, E. A., Crossett, R. N. O. (1967). The vertical distribution of attached marine algae in Malta. J. Ecol. 55: 361-371

Littler, M. M., Littler, D. S., Blair, S. M., Norris, J. N. (1985), Deepest known plant life discovered on an uncharted seamount. Science 227: 57-59

Littler, M. M., Littler, D. S., Blair, S. M., Norris, J. N. (1986). Deep-water plant communities from an uncharted seamount off San Salvador Island, Bahamas: distribution, abundance, and primary productivity. Deep Sea Res. 33: $881-892$

Lüning, K. (1971). Seasonal growth of Laminaria hyperborea under recorded underwater light conditions near Helgoland. In: Crisp, D. J. (ed.) Proc. 4th Eur. Mar. Biol. Symp. Cambridge Univ. Press, London, p. 347-361

Lüning, K. (1979). Growth strategies of three Laminaria species (Phaeophyceae) inhabiting different depth zones in the sublittoral region of Helgoland (North Sea). Mar. Ecol. Prog. Ser. 1: 195-207

Lüning, K., Dring, M. J. (1979). Continuous underwater light measurement near Helgoland (North Sea) and its significance for characteristic light limits in the sublittoral region. Helgoländer wiss. Meeresunters. 32: 403-424

Maggs, C. A., Guiry, M. D. (1987). Environmental control of macroalgal phenology. In: Crawford, R. M. M. (ed.) Plant life in aquatic and amphibious habitats. Blackwell, Oxford, p. 359-373

Mann, K. H. (1973). Seaweeds: their productivity and strategy for growth. Science 182: 975-981

This article was presented by $M$. J. Dring, Belfast. Northern Ireland
Mann, K. H. (1982). Ecology of coastal waters. Studies in Ecology 8. Blackwell, Oxford

Markager, S. (in press). Light absorption and quantum yield for growth in five species of marine macroalgae. J. Phycol.

Mathieson, A. C. (1979). Vertical distribution and longevity of subtidal seaweeds in northern New England, U.S.A. Bot. Mar. 22: 511-520

Mathieson, A. C., Hehre, E. J., Reynolds, N. B. (1981). Investigations of New England marine algae I: a floristic and descriptive ecological study of the marine algae at Jeffrey Point, New Hampshire, U.S.A. Bot. Mar. 24: 521-532

Matta, J. L., Chapman, D. J. (1991). Photosynthetic responses and daily carbon balance of Colpomenia peregrina: seasonal variations and differences between intertidal and subtidal populations. Mar. Biol. 108: 303-313

Neushul, M. (1971). Submarine illumination in Macrocystis beds. Nova Hedwigia, Beih. 32: 241-254

Norton, T. A., Hiscock, K., Kitching, J. A. (1977). The ecology of Lough Ine XX. The Laminaria forest at Carrigathorna. J. Ecol. 65: 919-941

Rabinowitch, E. I. (1951). Photosynthesis and related processes, Vol. II. Wiley-Interscience, New York

Raven, J. A. (1984). A cost-benefit analysis of photon absorption by photosynthetic unicells. New Phytol. 98: 593-625

Raven, J. A., Smith, F. A., Glidewell, S. M. (1979). Photosynthetic capacities and biological strategies of giantcelled and small-celled macroalgae. New Phytol. 83: 299-309

Sand-Jensen, K. (1988a). Minimum light requirements for growth in Ulva lactuca. Mar. Ecol. Prog. Ser. 50: 187-193

Sand-Jensen, K. (1988b). Photosynthetic responses of Ulva lactuca at very low light. Mar. Ecol. Prog. Ser. 50: 195-201

Sand-Jensen, K., Madsen, T. V. (1991). Minimum light requirements of submerged freshwater macrophytes in laboratory growth experiments. J. Ecol. 79: 749-764

Schonbeck, M. W., Norton, T A. (1980). Factors controlling the lower limits of fucoid algae on the shore. J. exp. mar. Biol. Ecol. 43: 131-150

Sears, J. R., Cooper, R. A. (1978). Descriptive ecology of offshore, deep-water, benthic algae in the temperate western north Atlantic Ocean. Mar. Biol 44: 309-314

Vadas, R. L., Steneck, R. S. (1988). Zonation of deep water benthic algae in the gulf of Maine. J. Phycol. 24: 338-346

Vermaat, J. E., Sand-Jensen, K. (1987). Survival, metabolism and growth of Ulva lactuca under winter conditions: a laboratory study of bottlenecks in the life cycle. Mar. Biol. 95: 55-61

Witkowski, E. T F., Lamont, B. B. (1991). Leaf specific mass confounds leaf density and thickness. Oecologia 88: $486-493$

Manuscript first received: July 1, 1992

Revised version accepted: September 21, 1992 